\title{
News Media Exposure and Political Communication among Libyan Elites at the Time of War
}

\author{
Abdul-Karim Ziani \\ Assistant Professor, Department of Media, Tourism and Arts, Bahrain University, Bahrain \\ Email: makram2008@hotmail.com \\ Mokhtar Elareshi \\ Former Lecturer, Media and Communication Department at the University of Tripoli \\ Former Head of the Department of Media at Azzaytuna University \\ Email: arishimok@yahoo.com \\ Khalid Al-Jaber \\ Assistant Professor, Political Communications, Gulf Studies Programme, Qatar University
}

Doi:10.5901/mjss.2017.v8n1p330

\section{Abstract}

\begin{abstract}
Many critical questions concerning the relationship between the news media and political knowledge involve the extent to which the media facilitate learning about news, war and politics. Political awareness - via the news media - affects virtually every aspect of citizens' political attitudes and behaviours. This paper examines how Libyan elites adopt the news media to access news and information regarding the current Libyan war and politics and how they use political communication and new media to build/spread political awareness. With the expansion of private and state-owned television in Libya, concern has grown that these new TV services will survive in providing information about citizens' interests, including the new, developing political scene. A total of 134 highly educated Libyan professionals completed an online survey, reporting their perceptions of issues covered by national TV services. This account centres on how those elites consume the media and what level of trust they have in the media and in information and what the role of the media in their country should be. The results show that most respondents, especially those who live outside the country, prefer using different Libyan news platforms. However, 50 per cent of these do not trust these channels as a source of information regarding the civil war, associated conflicts and politics in general. They have grown weary of coverage that represents the interests of those who run or own the services and consequently place little trust in the media. Spreading 'lies as facts' has affected the credibility of these services. Politically, these respondents wish the media to discuss solutions and act as a force for good, not for division. They also differed in the number and variety of national news sources that they reportedly used. This paper also highlights the role of social media, mobile telephony and the Internet, as well as the rapidly proliferating private and national media. These findings are also discussed in relation to the growing impact of online sources in Libyan society, social and political change and the emergence of new media platforms as new sources of information.
\end{abstract}

Keywords: Libyan civil war, Political communication, Libyan TV, Political awareness, Libyan elite, News coverage, War and conflict, Libyan politics, Social change

\section{Introduction}

Libya has witnessed a major change in its political, economic, social and cultural life following the Libyan 2011 uprising event. This has had an impact on the Libyan media as a whole. The vicissitudes of political, social and ideological differences, regional and partisan divisions and conflicts of power and leadership led the country into chaos (Kedze, 2015; Ronen, 2016; Shaoul, 2016). The spread of weapons among individuals, regions and militants has added major complexity to the political and social scene in Libyan. Intellectually, politically or regionally, the intensity of the dispute has drawn the country into a civil war with fighting between different militants and armed groups (Bhardwaj, 2012).

The media sector has observed a significant change in their structure and media discourse. For example, the media are no longer controlled by the former regime's legislation, regulations and political directives which obstructed these media. In other words, media regulation is practically non-existent (BBC News, 2016). To launch any medium, no 
authorised statement is needed after the fall of Gaddafi's regime and the ensuing political change. In addition, the Constitutional Declaration issued by the National Transitional Council (NTC) after the political change gave the right of freedom of expression, communication and ownership based on Article 14 (Al-Asfar, 2013). The number of TV, radio stations and newspapers has sharply increased in a very short period. This looks 'too good to be true' although it is clear that several political parties and some regional areas have, or own, different media platforms in addition to the stateowned and privately owned media. This means that most news outlets are bankrolled by private entities and business interests.

The country is not a safe place to work for reporters and media staff. Therefore, many recently launched media are based abroad and little is known about their backers (El Issawi, 2013a; Wollenberg \& Pack, 2013). This has increased the variety of media, which has significantly affected the local political scene. Libyan mainstream media - the majority of which have adopted strongly partisan stances - are key platforms for politicians to demonstrate their agendas. Overall, much has been written about the media landscape and change following the Arab uprisings of 2011. Justifiably, considerable discussion has taken place over the role of the proliferating private media, the breakneck growth in the influence of the Internet and, of course, the social media in particular. However, there has been little research that focuses on the subject through the eyes of the professional, highly educated Libyan elites who feel a keen understanding of the matters as local citizens. Therefore, this research is underpinned by quantitative audience research via an online survey. It aims to share the insights emerging from this research and to discuss the Libyan elites' views of current Libyan television and what they believe that television should be doing. This part of the paper focuses on how Libyan elites consumed Libyan television during the news coverage of two operations (Fajer Libya and al-Karama) ${ }^{1}$ and the level of trust they had in this coverage.

\section{Libyan Political Scene}

After the fall of Gaddafi's regime on 20 August 2011, there was no clear political force, or alliance of forces, that could lead the country politically. Instead, a multitude of actors - militias, armed groups and pro- and anti-Islamist groups engaged in power struggles, preventing the re-establishment of central government control (Lacher, 2015).

However, after Gaddafi seized power in 1969, he disbanded the republican political system in 1977 - a situation which lasted for four decades - and established a new era of the "Rule of the people", renaming the country alJamahiriya. Everything, then, was renamed according to this theme. The idea of the rule of the people, or the state of the masses, as some described it, was unique and unprecedented in that Libya was the only nation in the whole world that did not have either a president or a constitution. ${ }^{2}$ According to Gaddafi's political system, the ordinary Libyan people ran their own country through congress for their beneficiaries. The Green Book ${ }^{3}$ contained the essential idea of statelessness and of people managing their own affairs without state institutions. This Book was/is seen as the third universal theory, after those of capitalism and socialism (Vandewalle, 2006).

In February 2011, everything changed after the UN and what were called 'Libyan Friends' mandated a NATO air strike which led to the death of Gaddafi and the country descended into an ongoing civil war (Bhardwaj, 2012; Moore, 2015). Politically, the country has been governed by different governments from the National Transitional Council (NTC) in March 2011 to the General National Congress (GNC) in August 2012 (Barbour, Brown, Cordell, Fowler, \& Buru, 2016). Militias and Islamists campaigned and won a law aimed at a political ban on supporters of the Gaddafi regime, including the Prime Minister, Ali Zidan, the President of the National Congress, Mohamed El Magariaf, the chair of the main secular party, Mahmud Jibril, as well as judges, police and army officers and members of the boards of oil companies and banks (Clément \& Salah, 2014). Disagreement has also been seen between the Council of Deputies (CD) in Tobruk (which was formed following the June 2014 elections) and its supporters, the New General National Congress (NGNC) in Tripoli and its supporters and various jihadists and tribal elements controlling parts of the country. The GNC was supposed to hand

\footnotetext{
${ }^{1}$ Fajer Libya is an operation launched by a group of armed militias - mainly supported by Misrata - after the announcement of the Libyan Parliament election in 2014 and the failure of the Islam Wing Party to get seats in the Parliament. These militias attack all areas and institutions belonging to the Parliament, including Tripoli International Airport, and burned the oil-tank storage in South Tripoli. In contrast, al-Karama is a major military operation launched in May 2014 and led by the principal commander, Khalifa Hafter, against Islamist militants and extremist Islamic movements in Benghazi and eastern Libya.

${ }^{2}$ Although many argued that Gaddafi was seen as the official president by the international community, in fact Gaddafi himself did not accept this. Instead, he wanted to be just a leader who guided his followers to the right path.

3 The political system in Libya was based on the first parts of the Green Book which also contains a compilation of perspectives on what Libyan's social, political and economic organisation should look like. The Book is divided into three chapters. Volume I concerns the political system, Volume II is linked to the economic system and Volume III covers social issues.
} 
power to the unicameral CD. However, the former refused to lay down its mandate and continued as the NGNC, a now largely unrecognised rival parliament based in Tripoli (European Forum, 2016). The war, nevertheless, proved, on balance, to be a disaster and turned the country into the model of a 'failed state' (Kedze, 2015; Ronen, 2016; Shaoul, 2016).

\section{Politicisation of the Media}

During the Arab uprising of 2011, Libya had a call for change and, as a consequence, the country descended into civil war (Abou-Khalil \& Hargreaves, 2015). During this period, the propaganda battle between the regime and its opponents was fierce. TV channels are often associated with political and ideological factions. Therefore, there has been a dramatic expansion of TV channels, as well as other media platforms. For example, as of 2011, more than 50 Libyan (private and state) satellite TV channels were established (Al-Asfar, 2013). Indeed, the most popular genre of programme on Libyan television is the news (Dowson-Zeidan et al., 2014; Elareshi, 2013). It seems also that coverage of political issues is a key feature of programming during the last two or three years, especially during election time (June 2014). In fact, between them, news, current affairs, documentaries and features can occupy most of the viewing time. In particular, in June 2014, there was heavy political programming in the pre-election period, which resulted in the country's first election.

Moreover, because they have different directions, employees and ownerships, some of these channels have faced major obstacles from the government, the militias and other political interests, which have resulted in some channels stopping broadcasting, a situation also brought about by the current general unrest, the war and lack of security. Despite all the new Libyan media (print, TV and radio) being established, the Libyan media has not been able to become free from state or individual control, which means that they are still not free by any means (El Issawi, 2013a). Criticism now can lead to violent recrimination (Dowson-Zeidan et al., 2014; Pargeter, 2013). For example, Freedom House (2014) reports a deteriorating security situation for journalists and other members of the press who have suffered a spate of threats, kidnappings and attacks since the start of uprising. This has even led to a number of journalists losing their lives (El Issawi, 2013b; Freedom House, 2014). The media landscape in Libya mirrors the division and factionalism seen in the current conflict, reflecting broadly pro- and anti-Islamist lines. As a result, Libyan media outlets, especially TV, have become a focus for factional violence. Many media employees have been threatened, intimidated, kidnapped or even killed regardless of their editorial stance (Reporters without Borders, 2014). Opposing fighting groups and militias have targeted several TV channels and their staff in Benghazi and Tripoli. For example, Libya al-Wataniyah was attacked and taken by pro-Islamist militias in August 2014 and Al-Rasmiya TV had been controlled by a pro-Islamist militia for almost a year before both were taken off the air by the authorities in Tobruk.

Overall, Libya's media now reflects the wider circumstances of the state, with journalists, media workers and consumers being frustrated and poorly served (Gaub, 2014). Thus, instead of stimulating debates on political and social issues, Libyan television has become a mouthpiece for political parties, tribes and cities (Abou-Khalil \& Hargreaves, 2015; Gaub, 2014). These television services have become involved in local conflicts by supporting one group or one militia over another. For example, Al-Jazeera considers the Libyan Shield Force and the Libyan Revolutionaries Operations Room (LROR) to be the Libyan National Army, and the Zintani Brigades and the Libyan National Army (LNA), General Haftar's forces, to be illegal groups attempting a coup against the democratic institutions. Meanwhile, Al-Arabiya considers Haftar to be a representative of the LNA and strenuously promotes Operation al-Karama (Dignity).

\subsection{TV Consumption in Libya}

Television in Libya is still by far the most consumed media and the most important source of information (Al-Asfar, 2013; Altai Consulting, 2013; Elareshi \& Gunter, 2012b). One of the habits in Libya is watching TV every day, with the most popular channels, local or non-local, very well-known (Dowson-Zeidan et al., 2014). Despite the reliance on television as a source of information and news, Libyan people are cautious of agendas behind almost all TV services and there appears to be very little trust in the credibility of television channels as a result. It should be noted that the lack of trust in Libyan TV was also there before the Libyan uprising (Elareshi \& Gunter, 2012a).

\subsection{Libyan Television Channels}

Libyan broadcasts have developed over the years. However, there is still no specialised satellite news channel, such as Al-Jazeera TV or Al-Arabiya TV. Rather, news programmes broadcast on different television channels that also carry other types of programming. Satellite dishes provide Libyans with an opportunity to view a greatly increased variety of 
programming from local and non-local channels. Several Libyan television channels are already on the air, but others are pilot broadcasts or have closed because of funding problems or lack of staff and technology. These include Libya Toumast, Libya al-Hadath and Libya TV. Below are the ones that can be viewed in Libya via satellite or aerial and are free of charge:

al-Wataniyah TV (The National) (formerly known as al-Jamahiriya) was established in 1968 and was the only national terrestrial TV run by the Libyan Jamahiriya Broadcasting Corporation (cited in Menassat, 2011). The station was rebranded in 2012, but was taken over by pro-Islamist militias in August 2014 and became their mouthpiece (DowsonZeidan et al., 2014). The channel then split in two, with rival satellite feeds from Tripoli (pro-Islamist) and Tobruk (antiIslamist). The channel offers a mix of news bulletins, documentaries, live General National Congress (GNC) sessions and discussion shows (Altai Consulting, 2013).

al-Neba TV was launched in 2011 and is privately owned by Abdelhakim Belhadj (Libyan politician and military leader). He is the leader of the conservative Islamist al-Watan Party and is the former head of the Tripoli Military Council and former emir of the defunct Libyan Islamic Fighting Group, an anti-Gaddafi guerrilla group (Shideler, 2015). It was one of the few Libyan TV channels that broadcast from Tripoli after the Fajer Libya militia expelled all private channels, especially pro-government parliament channels. It is also a Qatar-supported Libyan TV station, seen as backing the Muslim Brotherhood in Libya. In March 2016, the channel was stopped after several gunmen raided its headquarters. The channel has been accused of instigating the fighting between Libyans and of supporting armed terrorist groups in Libya, such as Ansar al-Sharia.

al-Aseemah TV (The Capital) is a private and liberal-leaning TV station based in Tripoli. It was launched in July 2011 from Tunis. It broadcasts 24/7 from Tripoli, with about eight hours of live shows and 16 hours of pre-recorded content and re-runs. The channel has a dynamic image and branding. It also broadcasts cultural, political and entertainment programmes, with a strong focus on news and politics (Altai Consulting, 2013).

Libya al-Ahrar TV (Libya for the Free) is a private channel that started broadcasting from Doha, from where it is funded, in March 2011. It was managed by Mahmoud Shammam, the ex-Media Minister, and Ali al-Sallabi, a Muslim cleric and Islamist politician. The channel is considered one of the most influential TV channels since 2011. It broadcasts mainly news, debate and political programmes in Arabic, although one programme and one news bulletin are provided in Berber.

Misrata TV is a private channel established in August 2011 in Misrata. Mainly funded by the local council of Misrata, the channel uses the studio facilities of the old LJBC Misrata TV centre and broadcasts via satellite across Libya. It has two live political programmes, two religious shows and one 'social clinic' programme. Although popular only in Misrata, the channel has ambitions to become a national channel and targets Libya as a whole.

Benghazi TV (BTV) is a public channel established in 2012 and supported by the Benghazi Council and by Hossam al-Zawam (al-Karama operation supporter). ${ }^{4}$ The channel is renovating a mall in which to launch its studios as well as its own radio station. BTV was launched as a result of the lack of coverage of Benghazi city in mainstream Libyan TV. As such, BTV intends to provide reliable news and cultural shows about Benghazi, the rest of Libya and the world.

al-Libiya TV was launched in 2007, but was rebranded as al-Rasmiya (The Official) in 2011 following the uprising. Al-Rasmiya is also controlled by a pro-Islamist militia, but was taken off the air by the authorities in Tobruk. It has a rival feed from the east, which is dominated by the House of Representatives. The channel has no live content and offers only pre-recorded programmes because of managerial problems and security issues. In addition to social programmes, such as health and education issues, the channel offers political shows and debates.

Libya al-Hurra TV (The Free Libya) was the first private TV station in eastern Libya. It is an Internet television channel founded by Mohamed Nabbous who was killed by pro-Gaddafi troops during the second battle of Benghazi in March 2011. The channel was able to bypass government blocks on the Internet in order to broadcast live images from Benghazi across the world. It broadcasts a variety of interactive social shows and dialogue-based political programmes, as well as religious and sports programmes, from its studio in Benghazi.

Fezzan TV is a private TV channel started in 2012 after the fall of Sabha by a Libyan businessman (Mukhtar Khalid Omar). It is mainly concerned with promoting Libya's southern culture and broadcasts two hours of live content daily and 12 hours of recorded content. One of their most popular programme is 'Say Your Opinion', a 45-minute weekly discussion about the problems of the South.

Libya TV is a private television channel owned by a prominent Libyan businessman, which launched in May 2011 in Egypt. It offers a number of political dialogue programmes, with famous guests such as GNC members. Their Facebook page becomes interactive during their most popular show, Lammet Khot (Brothers Gathering), displaying a

${ }^{4}$ Phone interview with Hossam al-Zawam, head of Benghazi TV 
space to take people's opinions on Facebook during the show.

al-Tanasoh TV is a public channel launched in 2009 and led by the Fatwa Centre. It airs from Tripoli in favour of the National Conference and the Muslim Brotherhood. It promotes the Salafi ideology led by al-Sadiq al-Ghariani (the Grand Mufti of Libya since 2012).

Tobactes TV is a privately owned channel launched in July 2011 in Tunisia. It is funded by a businessman from Misrata, Khalid al-Bahlul, who also manages the Tobactes Radio Network. As of May 2013, the channel moved to Misrata and is reported to have studios in Tripoli. Its editor-in-chief is Omar Abu Ghadada. The channel has only pre-recorded content. ${ }^{5}$

Libya Awalan TV (The Motherland) is a private TV channel founded in Cairo in March 2011. It broadcasts a mix of political dialogue programmes, chat shows and entertainment, including Sahwat al Watan (The Motherland Voice), one of the most popular TV shows in Libya.

Libya One TV is a private Libyan TV station launched in September 2011. It broadcasts from Tripoli and is managed by Ali Gadam. It offers a few socio-political programmes such as Libyan Street.

Libya One TV is a privately owned channel launched in 2011 and managed by Hassouna Tatannaki. It broadcast from Cairo before it was stopped in 2015.

Libyan International Channel is owned by Abdul-Majeed Mliqth (Alliance Party) and was launched in 2014, before being stopped in 2015 after it was attacked by Fajir Libya.

Dardaneel TV is a privately owned channel launched in 2012 by the pro-Social Council of Bani Walid and based in Bani Walid city.

al-Khadrya TV (The Green) (now knows as al-Jamahiriya). This privately owned channel was launched in 2012 and broadcasts from Cairo. It is supported by pro-Gaddafi groups.

Al-Zintan TV is privately owned by al-Zintan Council. It was launched in 2012, but was stopped in 2014.

al-Qabael TV is a privately owned channel launched in 2014 by the pro-Gaddafi system. It airs from Cairo. It provides different programmes in which it supports the former regime.

Libya 24 TV is a privately owned, pro-Gaddafi channel, broadcast from London. It was launched in 2014 and is managed by Khalid el-Saadawi.

al-Aseema TV was launched in 2011 by the Government of National Salvation in Tripoli. It is seen as having a more liberal agenda.

\section{Research Questions}

- RQ1: How often do Libyan elites watch Libyan satellite TV?

- RQ2: Which Libyan satellite TV services are the most popular news sources among the Libyan elites?

- RQ3: What types of media content are preferred by Libyan elites on Libyan satellite TV?

- RQ4: To what extent do Libyan elites rely on Libyan channels as a 'source of news' about al-Karama and Fajer Libya operations?

- RQ5: In general, how credible do Libyan elites perceive news on Libyan TV services to be? And are some TV services seen as more credible than others?

\section{Methods}

The main data set out in this paper was obtained from an online questionnaire administered using a Google survey form. A stratified sample was used, which deliberately allowed the study to choose its participants to meet its objects and research questions. In this study, one segment of society was chosen, that of Libyan academic elites. This study follows the categories of Khalid Salah al-Din Hassan (2004) who classifies elites into sub-elites groups such as academic elite, political elite and media elite. The current study focuses on the academic elite because they have an influential part in public life and they also have an influence on university students. The questionnaire was posted online, targeting highly educated Libyans inside or outside Libya via Facebook and email in May-September 2015 with a primary focus on Libyan satellite TV consumption, political awareness and audience attitudes towards these platforms and information sources. From an initial contact sample of 144 respondents, filters were deployed to exclude responses from respondents who did not complete the questions, yielding a final sample of 134 participants.

\footnotetext{
${ }^{5}$ Phone interview with Khalid al-Bahlul, head of Tobactes TV
} 


\section{Findings}

A total of 134 responses were gathered and analysed, with a big gender ratio of $88.3 \%$ male and $11.7 \%$ female. $35.2 \%$ of respondents were aged over $47,24.2 \%$ were less than 35 , while $23.4 \%$ were aged between $41-46$ and $17.2 \%$ between 36-40. $40.6 \%$ of respondents indicated that they had more than 17 years' experience in their field, $21.1 \%$ had between 510 years, $20.3 \%$ had less than five years and $18 \%$ had $11-16$ years. $60.9 \%$ of respondents answered the survey from inside Libya, while $39.1 \%$ were outside.

\subsection{How Libyan elites consume TV services}

Respondents were asked about their habits of watching Libyan satellite TV services. $43 \%$ of respondents watched Libyan satellite 'quite often', while $30 \%$ did so 'always' and $27 \%$ said such viewing was 'rare'. When asked about their preferences, the most watched Libyan TV channels were: Libya al-Wataniyah TV (75\%), al-Karamha TV (68.8\%), alNabaa TV (67.2\%), al-Khadrya (63.5\%), Libya Awalan TV and Dardaneel TV (both 63.33\%), Libyan International Channel (58.96\%), Libya al-Ahrar TV (56.86\%), al-Tanasoh TV (51.87\%), Libya 24 (51.3\%), Misurata TV, Fezzan TV and Al Zintan TV (all 52.1\%), Benghazi TV (51.06\%) and al-Qabael TV (50.5\%). Similarly, a study by Altai Consulting (2013) found that Libyans had access to government news and political updates via al-Wataniyah TV, but also looked for other popular international TV channels. This could be because Libyans felt unhappy with the coverage of the Libyan uprising (Altai Consulting, 2013).

The analysis of access to media and main sources of information indicates the widespread use of satellite TV services and the higher than expected penetration of the Internet (Elareshi \& Al-Jaber, 2016). Data were presented both as the first choice and then as an aggregation of three prioritised choices. Most respondents indicated that the most watched types of Libyan TV programmes were: sports programmes (50.53\%), entertainment (49.73\%), talk shows (48.43\%), news (46.3\%), and political dialogues (45.5\%). In terms of Libyan channel preferences, the landscape was dominated by the state-owned channel al-Wataniyah as this service was ranked especially high in terms of quality of content, speed of news and trustworthiness (Altai Consulting, 2013). However, other Libyan TV channels, such as alAseemah, al-Ahrar and al-Hurra, are also popular and sustainable private Libyan channels.

\subsection{Reasons for watching news programmes}

Respondents were asked to state their reasons for watching Libyan TV news programmes. Most (36.5\%) said they watched news programmes because they wanted to know about local events and to view news of the war and military operations in Libya (31.7\%), to explore local channel's trends toward news coverage of the war in Libya (19.8\%), to identify news-treatment methods regarding the war in Libya (11.9\%), to watch out of curiosity (6.3\%) and to verify the validity of news circulating about the war from other sources (3.2\%).

When respondents were asked about their trust in Libyan television and whether they relied on local television as a primary source of information and news about what is going on in the nation, $83 \%$ of respondents indicated that they did not trust information on Libyan television, while some 11\% did. However, this result is not surprising as it is clear that most Libyan television channels are associated with different or unclear agendas (especially those broadcast and staffmanaged from outside the regime). Al-Wahaniyah TV was ranked high in terms of quality, trustworthiness and scope, while al-Aseemah TV, al-Ahrar TV and al-Hurra came in second place. These findings were consistent with earlier studies which found that respondents from all types of Libyan backgrounds tended to trust the main national television channels (Altai Consulting, 2013).

Respondents were asked to what extent they followed Libyan TV news channels as a source of news coverage of the al-Karama and Fajer Libya military operations. Some (13.5\%) indicated that they followed Libyan TV news channels, while $46 \%$ 'did not watch' and $40.5 \%$ did so 'sometimes'. Here, respondents were asked to indicate whether the alKarama and Fajer Libya operations were professionally covered by Libyan TV. 59.5\% of respondents said 'no', while $18.3 \%$ said 'sometimes' and $12.7 \%$ said 'yes'.

One of the questions asked respondents to indicate what types of programmes they watched on Libyan TV channels. The majority (61.1\%) watched news programmes, $55.4 \%$ watched political discussion programmes, while less than two-tenths of all respondents watched entertainment (18.4\%), sports (15.2\%) and talk shows (10.6\%). Further investigation was carried out to examine the reasons behind watching news programmes on Libyan TV channels. The main reasons given were: to access local events (37.3\%), to view news of the war and military operations in Libya (25.4\%), to confirm news of the war being circulated by other sources (12.7\%), to identify the attitudes and trends of 
channels in their news coverage of the war in Libya (9.7\%), to identify news-treatment methods of the war in Libya (8.2\%), and curiosity (4.5\%).

News about what is going on in Libya is delivered by different media from both local and non-local sources. Here, when respondents were asked how far they would go to verify information or whether they would depend on Libyan TV channels to learn about the al-Karama and Fajer Libya operations, nearly half (49.3\%) of respondents said they would depend on Libyan TV channels 'sometimes', while $35.1 \%$ did not do so and $7.5 \%$ did so 'often'. It should be noted that, in Libya, family members, friends and coffee shops are among other media and communication patterns used to verify news and information.

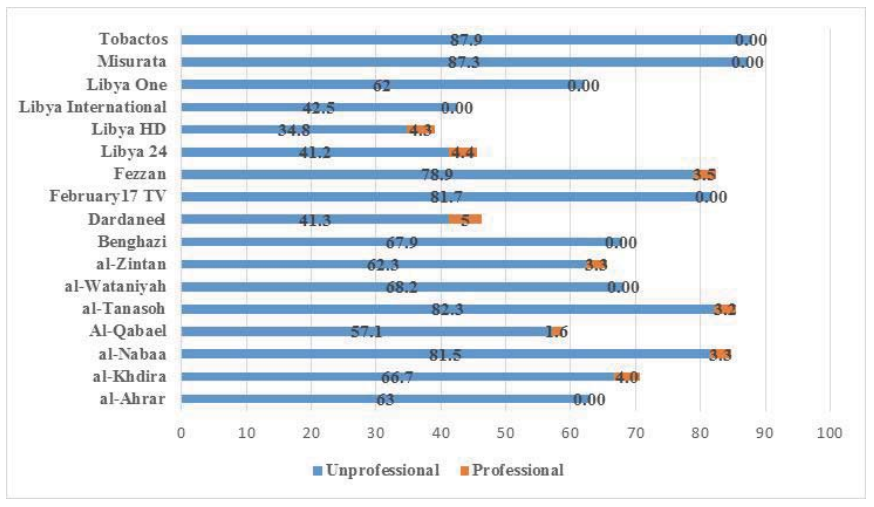

Figure 1: How channels are perceived in terms of their professionalism

It was also clear that respondents did not use Libyan TV channels as 'main' sources of news about the war led by the two operations (85.1\%), compared with $6 \%$ who did so. Here, respondents were asked to what extent they thought Libyan TV channels were professionally able to cover the two operations. $58.2 \%$ of respondents said the two operations were not professionally covered by Libyan TV channels, $19.4 \%$ said they were 'to some extent' and only $5.2 \%$ said the Libyan channels demonstrated professional coverage 'often'.

The above responses were noted when respondents indicated that all the Libyan TV channels had covered the war led by the two operations in an unprofessional way. These perspectives often varied across respondents. The Libyan TV channels seen as being the most unprofessional were: Tobactos TV (formerly Misrata TV) (87.9\%), al-Tanasoh TV (82.3\%), February 17 (81.7\%), al-Naba (81.5\%), Fezzan (78.9\%), al-Wataniyah (68.2\%), Benghazi (67.9\%), Libya alAhrar (63\%), al-Zintan (62.3\%), Libya One (62\%) and al-Qabael (57.1\%).

Further, the credibility of the news war by the two operations was tested. 18 Libyan TV channels were rated on a four-point scale with ' 1 ' being not biased and ' 4 ' being completely biased. Once again, almost all the respondents indicated that all the Libyan TV channels lacked credibility and were slanted when they covered the news war. The most biased Libyan TV channels were, in decreasing order: al-Karama (63.8\%), al-Zintan (61.4\%), Libya One (58\%), al-Naba (53.4\%), al-Tanasoh (51.1\%), February 17 (50\%) and Tobactos (50\%). These findings indicate the distrust felt towards news and information amongst Libyan elites and lead to the identification of factors that should be taken into consideration to understand information flows and optimise understanding of them. This could be because of the potentially divisive political and social issues that are led by rival groups in the absence of credible media coverage, as well as state security. This, as a whole, suggests that even the new private media outlets have been launched without clarity concerning their funding, production and agenda. This is because the national media in Libya is generally perceived as a political platform and is accused of spearheading 'national schism'. This finding is consistent with the view that Libyan TV outlets are increasingly accused of promoting certain agendas related to their owners' political views and the locations from which they broadcast (Al-Asfar, 2016; El Issawi, 2013a). 


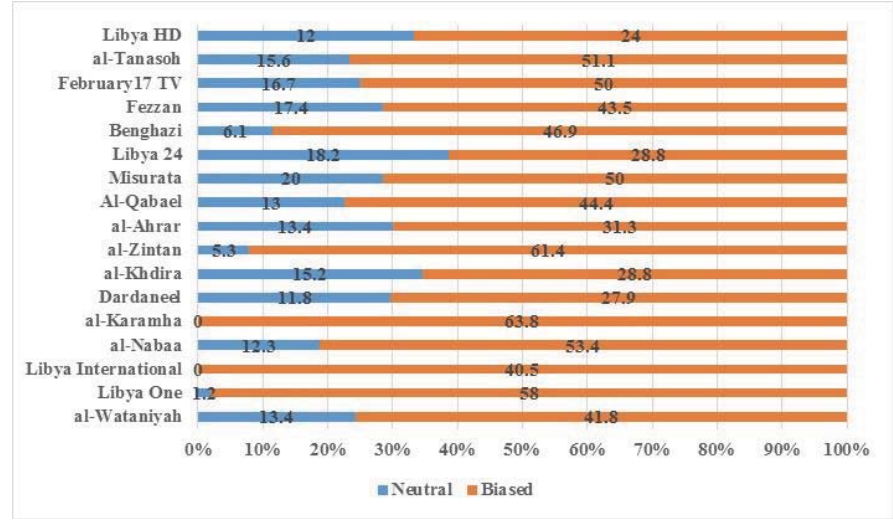

Figure 2: Credibility of Libyan TV channels

To examine the credibility of the news war, respondents were asked to indicate the most negative aspects of the coverage of the war led by the two operations. These were found to be: 'spreading lies as facts' (36.6\%); 'lacking specialised and professional media' (15.7\%), 'newscasts lacking neutrality' (12\%); 'newscasts lacking scoop' (11.2\%) and 'newscasts exaggerate when showing victories and defeats' (9\%). Further, respondents were asked to provide suggestions which could improve Libyan TV services. Overall, respondents suggested the following: Libyan TV should 'use media professional codes' (25.4\%), 'commit to neutrality in covering news of the war' (18.7\%), 'present both pros and cons of the operations' (17.2\%), 'scoop' (10.4\%) and 'adopting only specialists and analysts to discuss news issues' (9\%). This is an indication that Libyan elites are aware of media quality and of how local Libyan TV should be in terms of content and professionalism.

\section{General Discussion}

The current study provided an initial, systematic exploration of new Libyan TV channels. The study identified the types of channels that they are and looked at the impact of news TV exposure on political knowledge and political communication at the time of crisis. Unsurprisingly, the analysis has shown that Libyan elites frequently use satellite television for news and information about the country (RQ1). They are most likely to follow state-owned TV, e.g., al-Wataniyah TV, than others, even private-owned TV services such as al-Ahrar TV. The wide range of private and state-owned TV services could have helped to build free public opinion about what matters to the Libyans and help to unite them, but now it seems more likely to be used for division or 'national schism' (Al-Asfar, 2015; El Issawi, 2013b), war and unrest (RQ2) (Al-Asfar, 2016; Dowson-Zeidan et al., 2014).

The Libyan television-consumption pattern has increased not only since 2011, but since 2006 when new media platforms started to launch so-called 'Libya al-Ghad' (Elareshi, 2013). Some of these services were even able to compete with regional television services such as Al-Jazeera and Al-Arabiya TV (Elareshi \& Gunter, 2012b). This is acceptable because of the progressive development of Libyan television combined with the fact that any significant coverage of Libya in regional television services is either absent or misleading. Libyans report that they watch TV every day and use it more than any other platform (El-Nawawy, 2006; Lahlali, 2011). They also cite television as their main 'source of information'. There is also an indication that Libyans watch the state-owned broadcasters, especially evening news bulletins, and this is often seen as viewing for the whole family (Elareshi, 2013). However, when it comes to news covering the two operations, not many Libyan elites follow the local TV services; rather, they seek different platforms. This does not mean that the local TV services have been totally rejected by Libyan elites, but it does mean that they are not watched as often. This might be because the two operations were not professionally covered by the Libyan TV services and this could be because of a lack of professional skills, service agendas and trust (RQ3).

Libyan elites have several reasons for watching Libyan TV services, principally because they would like to be upto-date about local events and because they want to view news of the war and military operations in Libya. However, they do not view these local TV services as sources of information which they can trust. Therefore, they would go to seek information from other, different sources such as the Internet. This could be because these Libyan TV services are 
perceived as platforms which are associated with different or unclear agendas. This is clear when Libyan elites indicate that Libyan TV services have failed to cover the ongoing war between the two operations (al-Karama and Fajer Libya) and these services have a lack of professionalism in their news coverage (RQ4).

In this study Libyan elites have shown their interest in watching news programmes and other types of programmes such as entertainment, sports and talk shows. With regard to news programmes, accessing local events, receiving news of the war, and learning about attitudes and trends of channels were the most popular reasons for watching news.

The evaluation of the news credibility of Libyan TV services - as a whole - indicates that Libyan elites agree that these TV services lack credibility and are slanted when covering news of the war (RQ5). Despite the spread of new private and state-owned TV services in Libya recently, these services lack specialised media professionals, spreading lies as facts, and also lack neutrality in their newscasts, as well as lacking scoop (Al-Asfar, 2016). The current study suggests that these new branded and rebranded TV services should clearly adopt media professionals, providing fair coverage, providing both views on disputed topics, offer scoop and adopt only specialists to discuss matters. The clear lesson that these services should learn is that they need to be clearer about their agendas and their consumers and to adopt the standards of media professionalism in their broadcasts if they want to survive in this market. A long-term vision is much needed so as to define media professionalism and its role in the current political situation (El Issawi, 2013a).

\section{Conclusion}

The overall objective of this paper was to provide updated information about the Libyan television landscape, measuring consumption habits, perceptions of trust towards the news coverage of Fajer Libya and al-Karama, and attitudes towards political issues after the Libyan 2011 uprising, since when the country has experienced much political turmoil. Throughout the past six years, the media have played a major role, with what is referred as national media, state media, government media and official media, as well as private satellite channels, which have operated since 2011 and are owned by businessmen who are allied with different political agendas.

Since 2011, the Libyan media sector in general, and especially television, has witnessed significant change (AlAsfar, 2016). One of the greatest testaments to this is the number of private and state-owned television stations all over the country. Of the privately run television outlets, a handful have now been well acknowledged by Libyans, although their continued existence depends on whether Libyans need them and whether the population is able to absorb all these stations and productions as it seems that their programmes are clearly suffering not only a lack of branding (Altai Consulting, 2013; Buccianti \& el-Richani, 2015), but also financial, funding, policy and professional issues. After all, these services have been launched without government permission and without checks and licences.

What is clear is that Libyan television channels have played a substantial role during the unrest and are continuing to do so. However, a lack of professional skills and a lack of trust in these services have made it difficult to predict their future in general, especially when it comes to covering the civil war and associated conflicts, about which they have misled the Libyan citizens, allowing themselves to be transformed into propaganda tools. This, in turn, of course, has had an effect on the media outlets and their productions, which has led to them increasingly being viewed as political and military arms and thus they themselves have become targets (Abou-Khalil \& Hargreaves, 2015).

Today, Libya is generally referred to as a failed state. It is evident that Libyan society has deteriorated. The country seems to lack the basic components of pluralism, liberalism and democracy so that the media sector and others would find it difficult to build good relationships with their audiences. The media sector needs regulation and reconstruction, especially after the division in the State pyramid following the multiplicity of legislatures and governments (Al-Asfar, 2015).

In terms of the media's interests, employees need to be fully protected from assassinations and kidnappings. In turn, they need more training and greater skills and have to show that they are applying professionalism in their work. Media literacy efforts, through different platforms such as social media, should be used to inform the public politically and about their rights and should not be used as platforms for division through the spread of strife fitnah (Al-Asfar, 2016; Buccianti \& el-Richani, 2015). These new platforms have become ways of verbally abusing, insulting and slandering opponents and have even become instruments of threat, promoting hatred and incitement to violence. Watching these channels, it is easy to note the reality of life in Libya today, the programmes being filled daily with controversies, conflicts and rumours, reflecting the size of the political differences and the territorial conflict now taking place in Libya.

\section{References}

Abou-Khalil, N., \& Hargreaves, L. (2015). Libyan Television and its influence on the security sector. Washington, DC. Retrieved from 
SR364-The-Role-of-Media-in-Shaping-Libya's-Security-Sector-Narratives.pdf

Al-Asfar, M. (2013). Freedom of expression and information circulation in Libya between the legislator and authority orders. Azzatouyna University Journal, 8, 29-50.

Al-Asfar, M. (2015). Libyan satellite television and its role in the military and political conflict [السباسي الصراع في ودور ها الليبية الفضائيات العسكري Retrieved September 10, 2016, from http://studies.aljazeera.net/ar/mediastudies/2015/02/201528113223744200

Al-Asfar, M. (2016). The structural and legal reform of the media sector in Libya [ليبيا في الإعلام لقطاع و القانوني الهيكلي الإصلاح]. Retrieved October 19, 2016, from http://bit.ly/2et3UOT

Altai Consulting. (2013). Libyan media assessment: One year later. An assessment of the media landscape and consumption patterns.

Barbour, N., Brown, C. L., Cordell, D. D., Fowler, G. L., \& Buru, M. (2016). Libya. Encyclopaedia Britannica. Retrieved September 21, 2016, from https://www.britannica.com/place/Libya/Government-and-society

BBC News. (2016). Libya profile. Retrieved September 12, 2016, from http://www.bbc.co.uk/news/world-africa-13754900

Bhardwaj, M. (2012). Development of conflict in Arab Spring Libya and Syria: From revolution to civil war. Washington University International Review, 1(1), 76-97. Retrieved from http://pages.wustl.edu/files/pages/imce/migration /wuir_spring_2012.pdf\#page=76

Buccianti, A., \& el-Richani, S. (2015). After the Arab uprisings: The prospects for a media that serves the public. Retrieved September 20, 2016, from after-the-arab-uprisings-sept-2015.pdf

Clément, F., \& Salah, A. (2014). Post-uprising Libyan associations and democracy building in urban Libya. Built Environment, 40(1), 118-127. http://doi.org/http://dx.doi.org/10.2148/benv.40.1.118

El-Nawawy, M. (2006). US public diplomacy in the Arab world the news credibility of Radio Sawa and Television Alhurra in five countries. Global Media and Communication, 2(2), 183-203.

El Issawi, F. (2013a). Is Libyan media more free after the revolution? Retrieved September 20, 2016, from http://eprints.Ise.ac.uk/59913/

El Issawi, F. (2013b). Transitional Libyan Media: Free at last? Retrieved from http://carnegieendowment.org/2013/05/14/transitionallibyan-media-free-at-last/g3dk\#

Elareshi, M. (2013). News consumption in Libya: A study of university student. Newcastle: Cambridge Scholars Publishing.

Elareshi, M., \& Al-Jaber, K. (2016). The new media as alternative medium in the GCC region: the growing influence of social networks. In B. Gunter, M. Elareshi, \& K. Al-Jaber (Eds.), Social media in the Arab world: Communication and public opinion in the Gulf States (pp. 157-178). London, UK: I.B Tauris Publishers.

Elareshi, M., \& Gunter, B. (2012a). Credibility of televised news in Libya: Are international news services trusted more than local news services? Journal of Middle East Media, 8(1).

Elareshi, M., \& Gunter, B. (2012b). Patterns of news media consumption among young people in Libya. Journal of African Media Studies, 4(2), 173-191.

European Forum. (2016). Libya. Retrieved September 20, 2016, from http://www.europeanforum.net/country/libya\#top

Freedom House. (2014). Freedom in the world 2013: Tunisia. Retrieved September 6, 2016, from http://www.freedomhouse.org/report/freedom-world/2013/tunisia\#.U9vog-NdXy0

Gaub, F. (2014). A Libyan recipe for disaster. Global Politics and Strategy, 56(1), 101-120.

Hassan, K. (2004). Egyptian elite attitudes towards the Arab TV news channels of crisis management [إدارة نحو المصرية النخبة اتجاهات العربية للأزمات الإخبارية التلفزيونية القنوات. In Paper presented at the ten annul conference titled "The Modern Media and Arab Identity" (p. 976). Cairo: Cairo University.

Kedze, D. T. (2015). The 2011 Libyan Crisis: Would the African solution have been preferred? Conflict Trends. ACCORD, 1, 18-24.

Lacher, W. (2015). Libya's local elites and the political of alliance building. Mediterranean Politics, 21(1), 64-85. http://doi.org/10.1080/13629395.2015.1081451

Lahlali, E. M. (2011). Contemporary Arab broadcast media. Edinburgh: Edinburgh University Press.

Moore, C. (2015). Four years after the fall of Gaddafi: The role of the international community in stabilising a fractured Libya. Conflict Trends, 1, 50-56. Retrieved from http://www.accord.org.za/conflict-trends/four-years-fall-gaddafil

Pargeter, A. (2013). Libya: The rise and fall of Qaddafi. Journal of Islamic Studies, 24(3), 398-400.

Reporters without Borders. (2014). Newspaper editor gunned down on Benghazi street. Retrieved from http://en.rsf.org/libya-newspapereditor-gunned-down-on-26-05-2014,46354.html

Ronen, Y. (2016). Libya's descent into chaos. Retrieved September 23, 2016, from http://www.meforum.org/5686/libya-descent-intochaos

Shaoul, J. (2016). UK parliamentary report criticises Libya war but conceals its geo-strategic aims. Retrieved September 20, 2016, from https://www.wsws.org/en/articles/2016/09/21/liby-s20-s21.html

Shideler, K. (2015, March 3). U.S. backed rebel reportedly leads Islamic State in Libya. The Washington Times. Retrieved from http://www.washingtontimes.com/news/2015/mar///frank-gaffney-jr-us-backed-rebel-reportedly-leads-I

Vandewalle, D. (2006). A History of Modern Libya. Cambridge: Cambridge University Press.

Wollenberg, A., \& Pack, J. (2013). Rebels with a pen: Observations on the newly emerging media landscape in Libya. The Journal of North African Studies, 18(2), 191-210. http://doi.org/http://dx.doi.org/10.1080/13629387.2013.767197 